Aukje van Rooden

\title{
Kafka Shared Between Blanchot and Sartre
}

https://doi.org/10.1515/arcadia-2020-2010

\begin{abstract}
Ever since their translation in the course of the $20^{\text {th }}$ century, the works of Kafka have been widely appreciated by French intellectuals. Kafka's greatest admirers include Maurice Blanchot and Jean-Paul Sartre, both of whom consider his work an exemplary illustration of their own poetical-philosophical views. This is remarkable, because Blanchot's and Sartre's respective views are generally conceived of as opposites. Apparently, then, these two authors who are so divergent in their philosophical views and literary criticism, as well as in their own literary works, find themselves on the same page in their appreciation of Kafka. I will argue that this shared appreciation not only reveals some unexpected points of agreement between them, but also facilitates an interesting intellectual encounter between Blanchot and Sartre in the late 1940s. It is, we will see, only on the basis of an agreement with regards to Kafka's work that their ways can part.
\end{abstract}

Keywords: Franz Kafka, Maurice Blanchot, Jean-Paul Sartre, literature, imagination

\section{Introduction}

What does it mean to say that Franz Kafka is appreciated by two authors as disparate as Jean-Paul Sartre and Maurice Blanchot, that is, that he is shared between them? Obviously, it makes sense to claim that a notoriously ungraspable oeuvre like Kafka's lends itself to being appreciated in different and possibly even opposite ways. To be sure, Sartre might appreciate and highlight - or even see one side of Kafka's multifaceted works, and Blanchot another. This would imply that Kafka's work presents itself as a Janus-headed figure, showing either of his two faces depending on who is reading it. In this paper, I want to show, however, that it is not two different Kafkas who are appreciated by Sartre and Blanchot, but the same Kafka. Two authors, whose names can hardly be bracketed together

Corresponding author: Aukje van Rooden, Oude Turfmarkt 141-147, Postbus 94201, Amsterdam, The Netherlands, email: A.vanRooden@uva.nl 
without evoking a feeling of incongruity, ${ }^{1}$ apparently find themselves on the same page here, on the pages of Kafka's work. How do we understand this remarkable entanglement of Blanchot and Sartre that takes place in the name of Kafka?

"Shared between," partagé entre - for those familiar with Blanchot's texts in French, this formula will immediately bring to mind the two slopes of literature evoked by Blanchot in his seminal essay "Literature and the Right to Death." "D'un certain point de vue," Blanchot argues, "la littérature est partagée entre deux versants" (La part du feu 318). Literature is both shared and divided between two slopes or two angles that, although irreducible to each other, cannot be separated, and that, like an inside and an outside, always imply each other in an enfolded and mutual relation. ${ }^{2}$ The two slopes of literature identified by Blanchot are, to put it briefly, that of prosaic meaningfulness and that of poetic obscurity. Viewed from the first slope, literature is, according to Blanchot, a means to communicate, to name and describe, to grasp the world we live in. Viewed from the slope of poetic obscurity, however, "words become stronger than their meaning" (335) and the current meaning of the words strays, derails, and makes way for the expression of something significantly less lucid and communicative - for "speech descending slowly to the earth" (335). "All the people that we call poets come together on that slope" (333), according to Blanchot.

1 Cf. Opelz, "Blanchot et Sartre": "Le rapprochement de ces deux noms [Blanchot and Sartre, A. v. R.] est-il légitime ? Il semblerait, au contraire, que tout les éloigne. Les voir inscrits côté à côté, les prononcer tour à tour, les imaginer ensemble, peut paraître sinon une contradiction, du moins une discordance, un lapsus peut-être, faux pas ou contre-pas de la pensée qui évoque deux mouvements, deux mondes radicalement opposés, deux racines d'écriture qui poussent et se portent d'autant mieux qu'elles demeurent loin l'une de l'autre, chacune convenablement plantée et nourrie dans son sol propre." (198) Because of the incongruity between these two names, there is little scholarship that systematically assesses the relationship between Blanchot and Sartre. For fulllength articles apart from Opelz's, cf. Douglas; Swenson; Toumayan; Călin. For articles dealing in part with the comparison of Blanchot and Sartre, cf. Stoekl; Davies. For brief references to the relation between Blanchot and Sartre, cf. Colin; Hollier; Mesnard; Hill, Extreme Contemporary; Bident; Antonioli; Rajan; Denis. Almost without exception, these contributions focus on the difference between Blanchot and Sartre. My paper has to be read in prolongation of Opelz's essay, which is exceptional in bringing Blanchot and Sartre together.

2 Unfortunately, it is precisely the complex entanglement or coimplication of these two slopes that has been lost in the English translation of the verb partager. In the translation by Lydia Davis literature simply has two slopes: "If one looks at it in a certain way, literature has two slopes" (Blanchot, "Literature and the Right to Death" 330). A few pages later the text reads: "Literature is divided between these two slopes" (332). Simon Critchley also draws attention to this issue (71, note 24) and suggests translating the first phrase as "literature is dived between two slopes." Although emphasizing that it is a division between the two slopes, both Critchley and Davis, however, risk reducing the double meaning of partager - meaning both dividing and sharing - to the former. 
Although it is tempting to identify the landscape of literary works in clearly separated subcategories, varying from comprehensible narrative prose to impenetrable poetry, the problem of literature being partagée entre these two slopes is, however, that such a division is untenable: "Everyone understands that literature cannot be divided up, and that if you choose exactly where your place in it is, if you convince yourself that you really are where you wanted to be, you risk becoming very confused, because literature has already insidiously caused you to pass from one slope to the other" (333). It is thus not different works or different aspects of works that make up for the irreducible duplicity of literature - some communicative, others opaque - but that it is always one and the same work that is divided between or against itself.

Similarly, I would say that it is the same work of Kafka that is shared and divided between Blanchot and Sartre. I will claim that Kafka's work has opened a stage, a dynamic realm, where Blanchot and Sartre, despite their obvious disagreements, could meet. The sedimentation of this dynamic encounter is to be found in two essays conceived almost simultaneously and in close dialogue with each other: Sartre's “What is Literature?” (written in 1947) and Blanchot's "Literature and the Right to Death" (written in 1947-1948). ${ }^{3}$ At first sight, this encounter seems to be only one of polemic opposition. Where Sartre's programmatic plea for a littérature engagée clearly takes Blanchot's writings as one of its implicit targets of contention, ${ }^{4}$ Blanchot's "Literature and the Right to Death" is an equally implicit response to Sartre's programmatic plea. More than that, Blanchot's "Literature and the Right to Death" is in many respects a step-by-step contestation of Sartre's line of reasoning, beginning in the very first lines where Blanchot famously and simply answers Sartre's question "What is literature?" by suggesting "Let us suppose that literature begins at the moment when literature becomes a question." (300). What follows is a meticulous inversion of Sartrean poetics. Against Sartre's view of literature as a deliberate involvement in the world, Blanchot opposes a view of literature as a "refusal to take part in the world" (315). Against Sartre's

3 Sartre's Qu'est-ce que la littérature? was originally published between February and July 1947 in six parts in Les Temps Modernes, numbers 17-22, and reissued in Situations II (1948). In this paper I will refer to the English translation in “What is Literature?” and Other Essays. Blanchot's La litterrature et le droit à la mort originally appeared in two parts in Critique - "Le règne animal de l'esprit" in Critique 18 (November 1947) and "La littérature et le droit à la mort" in Critique 20 (January 1948) and were reissued together under the collective title "Littérature et le droit à la mort" in La Part du feu (1949) and as a preface to De Kafka à Kafka (1981). In this paper I will refer to the English translation in The Work of Fire.

4 As is also suggested by Denis, who claims that Sartre's plea for a committed literature is "avant tout anti-blanchottien" in its attempt to give an historical-dialectical account of literature ("Les fins de la littérature”). Cf. also Opelz, "Blanchot et Sartre” 220, note 94. 
view of literature as a form of action or praxis, Blanchot sees literature as "discrediting all action" (316) whereby "everything remains to be done" (317). And against Sartre's view of literature as instrumental to realizing one's freedom, Blanchot opposes a view of literature as a way of "separating myself from myself" (324).

At first sight, Blanchot's and Sartre's poetics seem to bluntly oppose each other; on closer inspection, however, it becomes clear that both authors are adopting each other's claims, twisting and turning them, and often reiterating them word by word in order to carve their own paths within the interstitial spaces thus created. As we will see, Kafka is never far away in this mutual adoption of the late 1940s. Sartre had already shown his indebtedness to Kafka in Being and Nothingness (1943), and in "What is Literature?" he continues to stress the "precious encouragement" (186) to be taken from Kafka's work. Blanchot, for his part, had already devoted an essay to Kafka - "Reading Kafka" (also from 1943) - before recurring to his work in "Literature and the Right to Death." Although Kafka is mentioned only in passing in the latter essay, it would hardly be an overstatement to say that the entirety of this essay, its enjeu, so to say, is pervaded with Kafka's presence. Not surprisingly, then, Blanchot republished "Literature and the Right to Death" as a preface to the collected volume De Kafka à Kafka (1981), edited more than 40 years later, thereby, in retroaction, presenting Kafka as one of the main guiding threads in his own itinerary.

Given the programmatic nature of their implicit dialogue, what is at stake is nothing less than the stake of literature itself. While Blanchot and Sartre are aggravating their mutual differences, it is their shared appreciation of Kafka's work that at the same time seems to draw them closer together. I believe Sartre's and Blanchot's essays should therefore be read in line with each other, in order to understand both the power of Kafka's work and the stakes of Sartre's and Blanchot's respective views. As Hannes Opelz notes in his illuminating paper on Blanchot and Sartre: "within their disagreement, there remains an agreement, a connection" ("Blanchot et Sartre" 199, trans. A. v. R.). ${ }^{5}$ It is this agreement, I would suggest, that bears the name of Franz Kafka. In this paper, I will address Blanchot's and Sartre's readings of Kafka separately, but I will also attempt to unravel the dynamics of this remarkable ménage à trois between Blanchot, Sartre, and Kafka that transpired in the late 1940s. I will show that, between them, Kafka's work incites not so much a disagreement with regards to the human condi-

5 Similarly, Christophe Bident concludes a long footnote on the comparison between Blanchot and Sartre by saying: "quelque chose d'incompréhensible des deux hommes se tient là, comme dans l'écart qui sépare leur proposition sur 'l'acte' ou 'les versions' de l'imaginaire” (205-6). I will return to the question of the imaginary in Blanchot and Sartre. 
tion or its meaninglessness, as one might expect, but rather, first of all, an agreement on the role of imagination. If Kafka's work is of particular relevance to both Sartre and Blanchot, it seems to be because of its capacity to irrealize” (as they both term it) reality through the power of imagination - a power both Sartre and Blanchot recognize and wish to account for.

\section{Sartre’s Kafka}

It would perhaps be understated to note that Sartre appreciated Kafka's work. As Marthe Robert explains in her influential study of Kafka's reception in France, Kafka was rather "adopted" or even "naturalized" by Sartre ("Kafka en France" 15). If it were not for Sartre, she holds, Kafka would never have gained the popularity amongst French readers he continues to have (15). ${ }^{6}$ Consequently, Kafka's popularity in France was immediately framed within the discourse of existentialism. Although Sartre never devoted a book-length study to Kafka, as he did to Baudelaire, Genet, and Flaubert, he refers frequently to Kafka's novels as exemplary works of existentialist literature that reveal the human condition, or, as Sartre has it in his infamous translation of Heidegger's Dasein, la réalité humaine, human reality.

As stated above, Sartre's reception of Kafka dates to Being and Nothingness, which describes the human condition in terms of "being-for-itself" or "conscious being," that is "condemned to be free" (152). According to Sartre, human beings are not only allowed but also obliged to assume the immeasurable task, the project, of seizing their own freedom. Kafka, for Sartre, may have succeeded in bringing to light most pertinently what this human task consists of. Focusing especially on Kafka's novel The Trial, Sartre claims, in Being and Nothingness: "This is certainly one of the meanings which Kafka's The Trial tries to bring to light, the characteristic in human reality of being perpetually in court. To be is to have one's freedom perpetually on trial." (523, emphasis J.-P. S.) Orphaned from divine and paternal authorities, human reality is to be perpetually in court, not in God's court or the state's, but in one's own court. Deprived of any larger, universal project we can tap into and that might reassure us in the choices we make, we are perpetually confronted with the ponderous freedom of designing our own life projects, or rather, of designing our lives as our own project. ${ }^{7}$

\footnotetext{
6 On Kafka and Sartre cf. also, amongst others, Robert, Introduction à la lecture de Kafka; Sokel; Prévost; Derins; Bogaerts.

7 With an unpredictable outcome: "It is this unpredictability which Kafka's art attempts to describe in The Trial and The Castle. In one sense everything which K. and the Surveyor are doing
} 
Typically, Sartre's existentialist reading is characterized as an example of the so-called allegorical readings of Kafka's work that were dominant for a good part of the $20^{\text {th }}$ century. ${ }^{8}$ Dismissing contextual information like the biographical or historical genesis of Kafka's work, as well as textual characteristics like narrative and style, these allegorical readings conceived of Kafka's work as primarily presenting his readers with an encoded message. "Those writing about Kafka," Claude Prévost holds, "all started from the same basic assumption: [Kafka's] oeuvre is a remarkable oeuvre that seems to present itself in encrypted language. The spontaneous move of the critic will thus be to break the code" (14, trans. A. v. R.). What surely encouraged this allegorical reading is the fact that Kafka's books are generally deprived of identifiable socio-historical references. "[H]is books were set in no particular time or place, his characters lacked names and full identities," Marthe Robert stresses, and "moreover, he did not address the people that constituted his own social environment or the readers of a specific geographic or linguistic sector, but rather addressed general men beyond common borders and limitations" ("Kafka en France" 71-72, qtd. and trans. by Bogaerts 72).

Over the years, this existentialist reading of Sartre has been increasingly received - and rejected, by amongst others, Blanchot ${ }^{9}$ - as an utterly reductive reading that ignores the literary qualities of Kafka's work and reduces it to its communicable and generalized content. Once the code of Kafka's encrypted language is broken, the riddle solved (e.g., that of the unreachable castle standing for an inaccessible transcendence), there is no point in rereading his work. Even if this accusation were valid for Sartre's analysis in Being and Nothingness, I believe it misses the point in the case of "What is Literature?" and cannot explain why Sartre and Blanchot are sharing their appreciation of Kafka. The difference between Being and Nothingness and Sartre's later work with regards to his reading

belongs strictly to them in their own right [...]. But at the same time [...] the acts have on principle a meaning which is their true meaning and which neither K. nor the Surveyor will ever know.” (Sartre, Being and Nothingness 289) Although oblivious of the ultimate truth of their actions, the human reality as presented by Kafka's protagonists is, according to Sartre, one of a vita activa, a life that transcends the given in order to reach for a still non-existent future, that is, of an existence in Sartre's meaning of the word.

8 For an analysis of the genesis of allegorical readings of Kafka, cf. Robert, "Kafka en France"; Prévost. According to Prévost, it was especially Max Brod's framing of Kafka's work in terms of religious allegories that encouraged this reception. Both Robert and Prévost clearly disapprove of this allegorical approach to Kafka's work.

9 Blanchot repetitively underlines the symbolic rather than the allegorical meaning of Kafka's work, in amongst others "Reading Kafka" and "The Language of Fiction" (both collected in The Work of Fire). I will return to this issue. 
of Kafka is also stressed by Jo Bogaerts, who - contra Robert - maintains that Sartre, over time, developed a less allegorical reading of Kafka. ${ }^{10}$ Rather than presenting literature as an allegorical depiction of human reality, Sartre's point in "What is Literature?" is to understand it as its realization, not as one realization amongst others but as the only possible realization of human freedom. Literature, Sartre claims, is a way "of wanting freedom," of offering, receiving, and experiencing it ("What is Literature?" 69, italics A. v. R.). Consequently, it is not so much Joseph K. in The Trial who puts his freedom on trial, but Kafka himself in writing this novel, and we, his readers, in reading it. ${ }^{11}$ Or, as Sartre has it: "[Kafka's] novels are a synthetic act of going beyond his situation as a man, as a Jew, as a Czech, as a recalcitrant fiancé, as a tubercular, etc., as were also his handshake, his smile, and that gaze which Max Brod so admired. Under the analysis of the critic [Kafka's novels] break down into problems; but the critic is wrong; they must be read in movement." (237) In other words, according to Sartre, we should not focus on the thematic content of Kafka's works, but investigate them as "the indistinctness of a movement of free creation" (237-238).

Rather than allegorical, the reading of Kafka suggested by Sartre in "What is Literature?" is therefore performative, or, if you like, revolutionary. ${ }^{12}$ Indeed, Sartre famously argues that speaking is acting, that to write is to act upon the world, to transform it. Hence, the main question for a writer, Sartre stresses in "What is Literature?," is: "How can one make oneself a man [or woman, A. v. R.], in, by, and for history?” (183) The relevance of Kafka's work, as Sartre notes, is implied in this historical dimension. "As for Kafka, everything has been said” (186), Sartre writes, pointing out "that he wanted to paint a picture of bureaucracy, the progress of disease, the condition of the Jews in eastern Europe, the quest for inaccessible transcendence, and the world of grace when grace is lacking. This is all true [...] But what we were particularly sensitive to" (186), he continues, is that in all of this "we recognize history and ourselves in history" (186). Here, Sartre counters an allegorical reading with a historical-transformative one. In other words: the fact that Kafka's works are not reducible to their themes, that indeed everything can be said of them, proves to Sartre that in all this something more is at stake, something that surpasses the meaning of these specific works and that has

10 Bogaerts's main focus is Sartre's 1962 presentation at the Moscow Peace Conference in which Sartre aims a rehabilitating Kafka against socialist disdain. I believe one can discern this shift in Sartre's view already in "What is Literature?"

11 A clear account of this aspect in Sartre's article can be found, amongst others, in Guerlac.

12 It would be interesting to explore the extent to which Sartre's and Blanchot's concepts of revolution developed in “What is Literature?" and "Literature and the Right to Death," respectively, are comparable. This would, however, surpass the limits of the present paper. 
to do with their historical-transformative power to realize human reality. Or, as Sartre puts it, Kafka's work "leads us to the moment when the literature of exis must be abandoned to inaugurate that of praxis. Praxis as action in history and on history." (194)

\section{Sharing/Dividing}

At this point, it seems easy to discern where Blanchot and Sartre diverge in how they read Kafka. Although Blanchot would subscribe to Sartre's claim of literature having a transformative or revolutionary power, it is the historical dimension of this power - and thereby in a sense the power of this power - that he is especially inclined to challenge in his response to Sartre's programmatic essay. Partly following Sartre's reading of Hegelian dialectics - or, to be more precise, of Sartre's reading of Alexandre Kojève's reading of Hegelian dialectics - Blanchot first subscribes to Sartre's claim that literary writers are historical actors, that their words contain a transformative power which is, in many respects, incompatibly great. "If we see work as the force of history, the force that transforms man while it transforms the world," Blanchot maintains, "the writer's activity must be recognized as the highest form of work" ("Literature and the Right to Death" 313). More than anyone else, the literary writer is free to create absolutely everything, and thereby capable of obtaining "freedom for himself and for the world" (313). The writer, Blanchot suggests, in line with Sartre and still borrowing his words from the latter, "denies everything he is, in order to become everything he is not" (315). Modern literature, most importantly perhaps that of the Surrealists but also that of Kafka, has revealed and cultivated this ability - or rather "privilege" (316), as Blanchot maintains - to deny the immediately given.

Although moving beyond - Sartre would say 'transcending' - the immediate place and time is the condition of possibility for the transformative power that both Blanchot and Sartre are ascribing to literature, it is, however, according to Blanchot also negating the very conditions to realize no matter what. According to Blanchot, the transcendence of the immediately given in and through literature, does not take place in history and on history (Sartre, "What is Literature?" 194), as Sartre would have it, but indeed "at the edge of the world and as if at the end of time” (Blanchot, "Literature and the Right to Death" 338). Even if literature can be called "the greatest ferment in history" (339), as Blanchot would grant Sartre, it is therefore history itself that rejects it. Literature is "spurned by history" (339, italics A. v. R.), déboutée de l'histoire. Even if a writer were to attempt making him- or herself a man or woman in, by, and for history, it is history itself that rejects this attempt, that cannot but reject this attempt, according to Blanchot. 
"Spurned by history, literature plays a different game" (339), Blanchot continues. Where the movement of Kafka's work, for the Sartre of "What is Literature?," seems to be the realization, in actu, of human reality, it is, for Blanchot in "Literature and the Right to Death," rather that of an "existence that is still inhuman" (339). As numerous commentators have pointed out, according to Blanchot this "inhuman" condition has been decisively formulated by Kafka in terms of the impossibility of death, that is, the impossibility of assuming the very power that makes us human, the power that is, as Blanchot has it, "within each of us [...] our most human quality" (337). ${ }^{13}$ Summarizing Kafka's oeuvre in a few lines towards the end of "Literature and the Right to Death," Blanchot sketches several variations of this impossible death:

A man enters the night, but the night ends in awakening, and there he is, an insect. Or else the man dies, but he is actually alive; he goes from city to city, carried along by rivers, recognized by some people, helped by no one, the mistake made by old death snickering at his bedside; his is a strange condition, he has forgotten to die. But another man thinks he is alive, when the fact is, he has forgotten his death, and yet another, knowing he is dead, struggles in vain to die; death is over there, the great unattainable castle, and life was over there, the native land he left in answer to a false summons; now there is nothing to do but struggle, to work and die completely, but if you struggle, you are still alive; and everything that brings the goal closer also makes the goal inaccessible. (338)

Where Sartre seems to recognize in Kafka a man employing the nothingness of his factual condition in order to act upon history, Blanchot seems to highlight the unemployability, the désoeuvrement, of this nothingness; he seems to recognize in Kafka's novels an endless struggle, an interminable oscillation, between being and non-being, absence and presence, that prevents them from acting upon history.

More generally, this interpretation of the difference between Blanchot and Sartre boils down to saying that while both Blanchot and Sartre recognize in Kafka's work a transformative force which lies in its ability to set in motion the movement beyond the immediately given, Sartre holds this to be a linear movement to the moment when literature inaugurates an act in and on history ("What is Literature?” 194), whereas Blanchot recognizes in Kafka's work a sliding back and forth, a fundamental indecisiveness that prevents it from acting upon history. The different game of literature revealed in Kafka's work is, according to the well-known interpretation of Blanchot's work, that of literary writing as an interminable oscil-

13 On the influence of Kafka on Blanchot's view of the impossibility of death cf., amongst others, Ellison; Guyer; Davies; Danta; Bruns; Hill, “A Kind of Struggle.” See also Blanchot's own translations of Kafka’s writings, published as Traduire Kafka (2019). 
lation between being and non-being. Following this interpretation, Kafka's influence on Blanchot would then be, as many commentators have it, to have pointed out that literature's condition of possibility (and impossibility) is this strange "lack of being" (Blanchot "Literature and the Right to Death" 339) which Blanchot, later on, begins to call neutral existence or the neuter. ${ }^{14}$

But let us not be in a hurry to adopt this interpretation and to understand the encounter of Blanchot and Sartre as a division between the inhuman and the human, the third and the first person, the inoperative and the operative, highlighted by Blanchot and Sartre, respectively. I wish to show that things are slightly more complicated and that Kafka inspires both Sartre and Blanchot almost in the same way. After all, not only is Blanchot inscribing himself in Sartre's poetic vocabulary rather than bluntly opposing it, but Sartre, for his part, would also be greatly mistaken if he were to claim that Kafka's works are populated with human protagonists or are situated within the midst of the world. Kafka's works seem to be especially significant - both to Sartre's and to Blanchot's thinking - because they are largely deprived of socio-historical references and more generally lack what we usually associate with ordinary living beings. Reading Blanchot's and Sartre's essays from the late 1940s, moreover, reveals that Kafka's work perhaps incites reflection not so much on the human condition, meaninglessness, or being's relation to death, but, first and foremost, and more specifically, on the working of the imagination. Typically, Kafka's works demonstrate the working of an imaginary realm which is not directly involved in the world, which lacks reality, is irrealized (a word used by both Blanchot and Sartre in the 1940s). ${ }^{15}$ If Kafka's work is particularly relevant to both of them, it seems to be because of its capacity to evoke and cultivate this irrealization of the world.

An inevitable source for understanding the interrelation between Kafka, Blanchot, and Sartre with regards to the working of the imagination is Sartre's double review of Blanchot's Aminadab and Kafka's The Castle - entitled "Aminadab or the Fantastic Considered as a Language" (1947) - in which he discusses the similarities between Blanchot's work and that of Kafka. Written simultaneously with "What is Literature?," this essay poses the question: "What must the nature of

14 In The Space of Literature (1955), Blanchot regularly speaks of neutral presence or existence; in The Infinite Conversation (1969) he speaks more specifically of "the neuter." In The Infinite Conversation, Blanchot himself is quite explicit, as explicit as Kafka allows him to be, about this "lesson" of Kafka: "What Kafka teaches us - even if this formulation cannot be directly attributed to him - is that storytelling brings the neuter into play" (384). On this "lesson" cf. also Davies. On Blanchot, Kafka, and the neuter cf. also Hill, "A Kind of Struggle."

15 As Françoise Collin rightly observes, "Blanchot n’a pas été insensible” (168) to the way Sartre conceptualizes the working of the imagination in The Imaginary. 
the fantastic be, in our time, if it enables Blanchot to find himself - upon adopting fantasy as his mode of expression - on the same terrain as Kafka?” (61). Sartre discerns a similarity between Kafka and Blanchot in the way they deploy a specifically modern or secular form of imagination. Where more traditional forms of fantastic literature reverted to otherworldly realms in order to reflect on the human condition, the modern writer, enclosed in an immanent universe, has to revert to another technique, that is, to the technique of inversion, that of turning upside-down or inside-out. Or as Sartre puts it: "Kafka and M. Blanchot, in order to make us see our condition from the outside without resorting to angels, have painted a world that is topsy-turvy [un monde à l'envers]" (73). For want of an otherworldly realm or Hinterwelt, it is only possible to transcend from and reflect on our being in the world, by pushing the human to the outside within, to its own outside, to the point where it becomes inhuman, almost an object - impersonal, as Blanchot would say. Sartre, like Blanchot, would thus suggest that Kafka's literary imagination reverts to a scarcely human position that is neither fully transcendent nor fully immanent, but rather outside-inside the world, or "at the edge of the world," as Blanchot would say.

According to both Blanchot and Sartre, the modern secular form of imagination that one can find in Kafka's works evokes an unworldly realm of socio-historical references without taking recourse to an otherworldly realm. In the end, however, this is also the point where their ways part. Sartre, in his endeavour to situate man's freedom, tries to find a point where the topsy-turvy world of Kafka's works is turned back on its feet, to prove that "[t]he author is in a situation like all other man" ("What is Literature?" 132, emphasis A. v. R.). ${ }^{16}$ What holds for the writer should, according to Sartre, also hold for the images springing from his imagination: "an image is not purely and simply the world denied, but is always the world denied from a certain point of view" (The Imaginary 184, emphasis J.-P.S.).

The necessity to root the imaginary within a certain point of view takes, in "What is Literature?," the form of a plea for engaged literature. But more generally, it seems to express a fear that had also motivated Sartre's investigation of the "extraordinary" ("Aminadab or the Fantastic" 61), and to his mind no doubt unsettling, resemblance between Kafka's and Blanchot's imaginaries. This is, I believe, the fear for an imaginary realm infesting and overrunning the real. ${ }^{17}$ After

16 Cf. also "Being situated is an essential and necessary characteristic of freedom." (133)

17 Although Sartre's plea for an engaged literature in "What is Literature?" can partly be explained by a shift in his oeuvre, from an individualistic account of freedom in Being and Nothingness (1943) to a trans-individual or social account of freedom in his later works, there is in my view thus also a direct connection between Sartre's concern for a situated imagination in The Imaginary (1940) and his call for an engaged literature. This fear of the imaginary realm infesting the real doubtlessly also 
all, if the imaginary cannot be traced back to the identifiable confines of an intentional consciousness or situated person, it loses the transformative, revolutionary power it potentially bears.

In the concluding paragraph of The Imaginary (1940), Sartre has already sketched what will happen when one is not able to distinguish the imaginary from the real, when the imaginary infuses the real to the extent of inactivating any form of inter-esse:

In that case everyone can observe in themselves a kind of standing back from the object contemplated, which itself slides into nothingness. Starting from this moment, the object is no longer perceived; it functions as an analogon of itself, which is to say that an irreal image of what it is becomes manifested for us through its current presence. This image could be purely and simply the object "itself" neutralized, nihilated [...] In the same way, the object, given as behind itself, becomes untouchable, it is beyond our reach. (193-194, italics J.-P. S.)

Interestingly, this passage on the neutralizing force of the real becoming an analogon of itself almost literally anticipates Blanchot's 1955 essay "The Two Versions of the Imaginary." In an attempt to avoid exactly this, Sartre, then, argues, pace Blanchot, for the necessity to preserve the difference between the imaginary and the real, to isolate the imaginary within the totality of the real, in order to control it, not as a force of existence itself, but as a power in the hands of mankind. This is where he aims at siding with Kafka contra Blanchot. The ultimate difference between Blanchot's Aminadab and Kafka's The Castle is, Sartre alleges, that Kafka's protagonist, K., does, in the end, still show signs of being human, in contradistinction to Blanchot's Thomas: "In The Trial [...] never for a moment do we lose sight of the fact that $\mathrm{K}$. is struggling to defend his honourable character, his life. But why is Thomas struggling? He has no definite character, he has no purpose, he hardly interests us" ("Aminadab or the Fantastic" 76).

\section{Blanchot's Kafka}

It would be no surprise if Blanchot's essay "The Two Versions of the Imaginary" immediately draws from Sartre's The Imaginary. Indeed, the confusion of the real and the imaginary Sartre fears is exactly what Blanchot recognizes in the work of Kafka. It can therefore be argued that Blanchot's point, in discussion with Sartre,

motivates Sartre's rigid distinction, in "What is Literature?, " between the prose writer (who is "in a situation in language", 30) and the poet (who is "outside of language. He sees words inside out as if he did not share the human condition, and as if he were first meeting the word as a barrier as he comes toward men." 30). 
is that there is no exact point where the real and the imaginary diverge, and consequently - where his own and Sartre's views can part ways, where the topsyturvy world can be put back on its feet. Contrary to the dominant reception, I believe that Blanchot's reading of Kafka, at least in the 1940s and in his discussion with Sartre, is not the one stressing the impossibility of death or the neuter, thereby countering an existentialist reading of Kafka, at least not primarily. At the time of "Literature and the Right to Death" there is another theme that is more central to Blanchot: that of the absoluteness of the literary act which Blanchot recognizes in Kafka's uncompromising attitude towards literature. "All I am is literature, and I am not willing or able to be anything else" (Blanchot, "Kafka and Literature” 12, emphasis A. v. R.), Blanchot quotes Kafka in the opening of his 1949 essay, written almost simultaneously with "Literature and the Right to Death."

According to Blanchot, what is unique in Kafka, or at least uniquely pertinent in Kafka's case, is that he has "devoted his entire existence to his art" ("Kafka and Literature" 13). ${ }^{18}$ "How can existence be completely devoted to a concern for arranging a certain number of words in some order? That is what is not so clear," Blanchot remarks in this early essay on Kafka (13). Paradoxically and in contradistinction to Sartre, Blanchot is not focusing on Kafka's fictional work like The Castle or The Trial, but on his diaries and letters and, more so than Sartre, he seems to be sensitive to what this absolute devotion means for the freedom of literary imagination that both Blanchot and Sartre have recognized in Kafka's work. If Kafka's name represents anything, for modern literature in general and for Blanchot of the 1940s in particular, it is to have revealed the fact that literature, above all, cannot be but a matter of All or Nothing, an act without reserve, ${ }^{19}$ like the Abrahamic offering of his son. As Blanchot puts it: "A writer cannot just drop out of the game. As soon as he starts writing, he is within literature and he is there completely" (14, emphasis A. v. R.).

The game that spurns literature from history and that makes Kafka's work inoperative is thus not so much that of an inhuman realm or a slipping back and forth between being and non-being - characteristics that Sartre to a large extent also recognizes - but the fact that writing is a game one can only completely drop into, and never out of, where one leaves every point of entry or exit behind. As

18 Something similar has been said about Blanchot. The publisher's preface to Blanchot's The Book to Come reads: "Maurice Blanchot, novelist and critic, was born in 1907. His life is wholly devoted to literature and to the silence unique to it" (ix).

19 Of course, this "without reserve" is closely related to Blanchot's non-dialectical reading of Kojève-Hegel, and Blanchot's and Sartre's diverging interpretations of the Kojèvian-Hegelian notion of negation are central to their concordant discordance. A good account of Blanchot's interpretation can be found in the section "From work to worklessness" in Hill, Extreme Contemporary. 
soon as one starts to write, one is on the side of literature, and one is there completely - irrespective of the intention, appeal, or engagement that might have spurred one to write. This is a hyperbolical logic - a hyperbologic, as Philippe Lacoue-Labarthe would say, a logic that, in Jacques Derrida's description (in his preface to Lacoue-Labarthe's Typography), “converts the gift of everything into the gift of nothing" (Derrida 41, note 29). ${ }^{20}$ Although "Literature and the Right to Death" is in many respects a dialogue with Georg Wilhelm Friedrich Hegel (and Emmanuel Levinas) irrespective of Sartre, in its emphasis on the absoluteness of the imaginary act it seems also to be influenced by this hyperbologic recognized by Blanchot in Kafka's attitude towards literature. ${ }^{21}$ Kafka's work not only presents the human condition "from without," but also reveals that this presentation always takes place from the point of view of the whole, that is, from a point of view that is not a point, that is nowhere: "Unreality begins with the whole. The realm of the imaginary is not a strange region beyond the world, it is the world itself, but the world as entire, manifold, the world as a whole" (Blanchot, "Literature and the Right to Death” 316).

In the 1940s, Blanchot's own concept for this hyperbolical logic seems to be the concept of the symbolic, literally meaning, freely translated, the logic of what is taken together. In two essays dealing with the work of Kafka - "Reading Kafka" (1943) and "The Language of Fiction" (1949) - as well as in the (unfortunately only partly available) "Prière d'insérer" added to the 1942 publication of Aminadab Blanchot distinguishes this symbolic meaning of literature from an allegorical and mythical meaning. ${ }^{22}$ Like Sartre, Blanchot thus distinguishes his reading of Kafka from an allegorical reading. According to Blanchot, the meaning of an allegory

20 "[T]his hyperbologic regularly converts the gift of everything into the gift of nothing, and this latter into the gift of the thing itself [...]. Without being negative, or being subject to a dialectic, it both organizes and disorganizes what it appears to determine" (Derrida 41, note 29). It would be interesting to compare this hyperbological gift with what Sartre in "What is Literature?" calls the mutual gift of generosity of the writer and the reader.

21 Interestingly, this would imply that Kafka finds himself on the same page as Marquis De Sade as the writer par excellence because writing was for him a matter of All or Nothing. Blanchot's "Literature and the Right to Death" might therefore best be read as an alternative view on literary commitment, in which the commitment does not lie in the commitment to a socio-political cause, but in the absolute commitment to literature itself.

22 This "prière d'insérer" reads: "Tout récit qui ne se contente pas de visées réalistes exige un sens secret dont la lente mise au jour est liée aux péripéties de la narration. Si le sens correspond sans ambiguïté à l'anecdote, mais peut aussi être exprimé complètement en dehors d'elle, c'est une allégorie. Si au contraire, il ne peut être saisi qu'à travers la fiction et se dissipe dès qu'on cherche à le comprendre pour lui-même, c'est un symbole. [...] Le sens d'une histoire, c'est l'histoire ellemême. Elle semble mystérieuse, parce qu'elle dit tout de ce qui justement ne supporte pas d'être dit.” This text is available in the depository of Le Feu Follet. Cf. www.edition-originale.com. Ac- 
relies on an ideal realm, since an allegorical story "sends us back to an idea of which it is the sign" ("The Language of Fiction" 78). Myth, on the contrary, "implies an actual presence" of meaning, a meaning that is fully constituted by the story and that one can live in and live by (78, italics M. B.). A symbol, however, is the evocation neither of an ideal world, nor that of a meaningful present world, but is "le renversement du monde réel dans son ensemble" (Blanchot, "Le langage de la fiction" 84). In an illuminating paragraph of "Le langage de la fiction" that is strangely missing in the English translation, Blanchot explains what this entails:

Le propre du récit symbolique est de rendre présent ce sens global que la vie de chaque jour, étranglée dans ses événements trop particuliers, nous permet rarement d'atteindre et que la réflexion, qui n'en retient que l'aspect intemporel, ne nous permet pas d'éprouver. Nous rencontrons rarement le monde, nous touchons rarement l'existence, nous n'éprouvons pas notre situation comme celle d'un être qui dans chaque événement se saisit tout entière et saisit tout ce qu'il y a dans l'événement. (84)

The removed paragraph continues with a reference to Sartre and the imaginary:

Le symbole trouve ici une aide dans la nature de l'imagination. L'acte même d'imaginer, comme l'a bien montré Sartre, suppose qu'on s'élève au-dessus des objets réels particuliers et qu'on s'oriente vers la réalité prise dans son ensemble, non, il est vrai, pour la concevoir et la vivre, mais pour l'écarter et, dans cet écart, trouver le jeu sans lequel il n'y aurait ni image, ni imagination, ni fiction. [...] Cependant, l'imagination va plus loin. Elle ne se contente pas de se donner, dans l'absence d'un objet en particulier, cet objet, c'est-à-dire son image ; son mouvement est de poursuivre et d'essayer de se donner cette absence même en général et non plus dans l'absence d'une chose, cette chose, mais à travers cette chose absente, l'absence qui la constitue le vide comme milieu de toute forme imaginée et, exactement, l'existence de l'inexistence, le monde de l'imaginaire, en tant qu'il est la négation, le renversement du monde réel dans son ensemble. C'est dans ce mouvement que l'imagination devient symbolique. (84)

Although Blanchot thus agrees with Sartre that the act of imagining entails a transcendence of the real, he emphasizes that this transcendence does not follow from an attempt to conceive and live (in) the real, but has to be understood as a game or movement in which the real as such is put at stake, in its entirety.

For Sartre, Kafka shows that imagination is rooted in human struggle. For Blanchot, he serves as a lead in proving that imagination is somewhat dislocating in its movement to embrace the real in its entirety. Taking cue from the phrase: “The head clerk called” in Kafka's The Castle, Blanchot demonstrates that the very

cessed on 7 Sept. 2020. For a detailed account of the difference between the allegorical, mythical, and symbolic as introduced by Blanchot, cf. MacLaghlan. 
same phrase, and in extension, the very same text, can work either within an everyday context, such as in a memo from one's secretary, and within a work of literature. "The words are the same, I give them roughly the same meaning," Blanchot holds ("The Language of Fiction" 74). "And yet, from the reading of my memo book to that of the novel, the difference is great" (74). Contrary to the meaning this phrase has in everyday life, the symbolic meaning it takes in the case of literature "can only be a global meaning, which is not the meaning of such an object or such an action taken in isolation, but that of the world in its entirety, and of human existence in its entirety" (79). ${ }^{23}$

In line with Sartre's essay "Aminadab or the Fantastic Considered as a Language,” Blanchot also reassesses literature's religious value with this emphasis on the symbolic. Indeed, both Blanchot's and Sartre's readings of Kafka stem from an attempt to assess the possibility, the value, and the truth of literature beyond onto-theology, and both seek, no doubt, to avoid the overly theological interpretations of Kafka's work (such as Max Brod's) that were also current at the time. In doing so, however, Sartre shies away from acknowledging what I called the hyperbological logic of Kafka's writing discerned by Blanchot. After all, for Sartre, the all-encompassing embracement of everything and nothing seems to be accessible only from the theological viewpoint of an otherworldly realm, thereby disabling a concretely rooted, historically situated point of view. For Blanchot, however, this hyperbolical logic is not theological; rather, it opens the way for what he calls, in "Kafka and the Work's Demand” (1958), the “'Abraham' perspective” (70), which is not the perspective of an otherworldly divine entity situated beyond the world, but that of the world itself, taken in its entirety:

It is necessary to read them [i.e., the images of deprivation of the world sketched in Kafka's diaries, A.v.R.] not from the common Christian perspective (according to which there is this world, then the world beyond, the only one which has value, reality, and majesty), but always from the 'Abraham' perspective. (70)

In aesthetic terms, this Abraham perspective means that art does not affirm "another world, at least not if it is true that art has its origin, not in another world, but in the other of all worlds" (75, emphasis A. v. R.). ${ }^{24}$ The difference between "an-

23 Although Blanchot, in his later works, seems to denounce symbolic reading as the worst way to read a literary text (cf. The Book to Come 84 and The Infinite Conversation 259), he is, I believe, in fact arguing in favor of the necessary failure implied in the global meaning 'grasped' by a symbolic reading.

24 This other of all worlds is what Blanchot, in "Literature and the Right to Death," calls the "unreality" (irréalité, 76) and moreover shows a slight but important shift in meaning compared to what Sartre, in The Imaginary, had called "irreality." 
other world" and "the other of all worlds" is crucial. Rather than acting in view of a world beyond, the Abraham perspective is, to reiterate Derrida's description of the hyperbologic, the perspective of the one who receives the totality of the world in sacrificing it in its totality. Anna Glazova has righty described this Abraham perspective as “the paradox of sacrificing the future for the future's sake” (209), a paradox that Blanchot explains as follows:

\begin{abstract}
What is demanded of Abraham is not only that he sacrifice his son, but God himself. The son is God's future on earth, for it is time which is the Promised land - the true, the only dwelling place of the chosen people and of God in his people. Yet Abraham, by sacrificing his only son, must sacrifice time and time sacrificed will certainly not be given back in the eternal beyond. The beyond is nothing other than the future, the future of God in time. The beyond is Isaac. ("Kafka and the Work's Demand" 61)
\end{abstract}

It is, I believe, this idea of the other of all worlds opened by sacrificing the future for the future's sake that contains, for the Blanchot of the 1940s, the demand, and truth, of writing as revealed by Kafka.

Moreover, if one investigates the genesis of Blanchot's own fiction in the 1940s - especially Thomas the Obscure (1941/1950), Aminadab (1942), and The Last Word (1947) - it is likely to become clear that the search for this Abraham perspective, for this imaginary centre, this point of view from nowhere, was also motivating Blanchot's own fictional writings. ${ }^{25}$ The genesis of Blanchot's fiction of the 1940s can be traced, tentatively, on the basis of the unpublished handwritten and typewritten manuscripts recently purchased from the archives of Blanchot. ${ }^{26}$ This collection offers a wealth of precious information for Blanchot scholars, including the unpublished handwritten and typewritten versions of Thomas L'Obscure - at that time called Thomas Le Solitaire (from 1932) - as well as the unpublished handwritten and typewritten versions of the short fiction text Le dernier mot from 1935 (not published until 1947) and the unpublished, handwritten first version, from 1941, of Aminadab (published in 1942). In all these cases, Blanchot's numerous changes boil down to making the texts more abstract, more purified, and to removing all recognizable socio-historical details (for instance those evoking mid-20 ${ }^{\text {th }}$ -

25 In the new version of Thomas the Obscure (1950), Blanchot explains that the much briefer new version expresses "la recherche d'un centre imaginaire" (7) of the earlier 1941 version. Although we can speculate, it is uncertain if Blanchot was familiar with Kafka's texts during the 1930s. Blanchot's translations of Kafka's writings, published with Kimé in 2019, can no doubt help to date Kafka's influence more precisely.

26 The Parisian library Le Feu Follet offers handwritten and typewritten manuscripts from Blanchot's archives and briefly presented them in their 2015 and 2016 catalogues. These manuscripts stem from the heritage of Blanchot's sister. 
century Paris, in Thomas le Solitaire). ${ }^{27}$ Together with Blanchot's preoccupation with the symbolic in the 1940 s, these stylistic revisions may demonstrate that the lesson Blanchot took from Kafka, at that time, is not so much that of an impersonal writing as is commonly thought, but that of the Abraham perspective, that is, that of a symbolic writing from the all-encompassing point of view from nowhere - of literature as the opening of the realm of God, the ultimate creator, but now brought into the world, as an absolute outside within the heart of being.

It is highly probable that Blanchot was especially receptive to this lesson of Kafka because of the dialogue he was undertaking with Sartre's work at the time. Although Blanchot does not explicitly criticize the interpretation of Kafka's power of imagination given by Sartre in "Aminadab or the Fantastic Considered as a Language," he clearly anticipated the Abraham perspective of Kafka's imagination, specifically in one of the key passages of "Literature and the Right to Death," clearly written in response to Sartre's "What is Literature?" and The Imaginary. In this passage, Blanchot describes what he calls here the "global negation" (316) of and by literature, thereby neatly summarizing how he adopts and stretches Sartre's reading of Kafka:

A writer's influence is linked to this privilege of being master of everything. But he is only master of everything [...]. The truth is that he ruins action, not because he deals with what is unreal, but because he makes all of reality available to us. Unreality begins with the whole. The realm of the imaginary is not a strange region situated beyond the world, it is the world itself, but the world as entire, manifold, the world as a whole. That is why it is not in the world, because it is the world, grasped and realized in its entirety by the global negation of all the individual realities contained in it, by their disqualification, their absence, by the realization of that absence itself, which is how literary creation begins. $(316)^{28}$

\section{Conclusion}

By drawing attention to the specific working of the imagination, Kafka brings Blanchot and Sartre closer together than one might expect on the basis of their

27 A remarkable change, from the perspective of Kafka's alleged influence on Blanchot's work in the 1940s, is the change from the third person in the early version of Le dernier mot (1935) to the first person in the 1947 published version - a change that counters the dominant reception of Blanchot's work.

28 One could perhaps say, as suggested by Tilottama Rajan, that Blanchot's "Literature and the Right to Death" is an "unworking" of the later Sartre "through a working back to an earlier Sartre whose focus on 'nothingness' had much in common with Bataille's 'inner experience' and with what Foucault calls Blanchot's 'thought of the outside'.” (81) 
respective poetical-philosophical views. Unravelling the genesis of their programmatic encounter in the $1940 \mathrm{~s}$ has revealed that their ultimate disagreement is more subtle and more complex than is commonly thought. As we have seen, both Blanchot and Sartre recognize in Kafka the working of an imaginary realm that is uniquely modern and secular while at the same time not directly involved in the socio-historical world; according to both, this imaginary realm bears, precisely for this reason, the revolutionary historical force to change everything. Nevertheless, although Kafka seems to be the one author who brings them together, he is also the one who takes the lead in drifting them apart, be it again in an unexpected manner. Sartre - basing himself exclusively on Kafka's fictional works and surprisingly ignoring Kafka's personal testimonies - recognizes in Kafka's writings the uniquely human struggle to transcend his situation as, for example, a Jew or a Czech, while being inevitably also bound to and motivated by this very same situation. Blanchot - uniquely basing himself on Kafka's diaries and letters and surprisingly ignoring Kafka's fictional works - recognizes in Kafka the hyperbolical Abrahamic logic of literature by which the totality of the world is sacrificed in order to receive it in its totality - a Kafkaesque gift Sartre was no doubt hesitant to accept.

\section{Works Cited}

Antonioli, Manola. L'écriture de Maurice Blanchot: Fiction et théorie. Paris: Kimé, 1999.

Bident, Christophe. Maurice Blanchot: Partenaire invisible. Seyssel: Champ Vallon, 1998. Translated as Maurice Blanchot: A Critical Biography. Trans. John McKeane. New York: Fordham UP, 2018.

Blanchot, Maurice. “Le Langage de la fiction.” La Part du feu. Paris: Gallimard, 1949. 80-91.

Blanchot, Maurice. "Littérature et le droit à la mort.” La Part du feu. Paris: Gallimard, 1949. 291-331.

Blanchot, Maurice. "The Two Versions of the Imaginary.” The Space of Literature. 1955. Trans. Ann Smock. London and Lincoln, NE: U of Nebraska P, 1982. 254-63.

Blanchot, Maurice. The Space of Literature. 1955. Trans. Ann Smock. London and Lincoln, NE: U of Nebraska P, 1982.

Blanchot, Maurice. The Book to Come. 1959. Trans. Charlotte Mandell. Stanford, CA: Stanford UP, 2003.

Blanchot, Maurice. The Infinite Conversation. 1969. Trans. Susan Hanson. London and Minneapolis, MN: U of Minnesota P, 1993.

Blanchot, Maurice. De Kafka à Kafka. Paris: Gallimard, 1981.

Blanchot, Maurice. "Kafka and the Work's Demand." The Space of Literature. Trans. Ann Smock. London and Lincoln, NE: U of Nebraska P, 1982. 57-82.

Blanchot, Maurice. The Work of Fire. 1949. Trans. Charlotte Mandell. Stanford, CA: Stanford UP, 1995.

Blanchot, Maurice. "Literature and the Right to Death." Trans. Lydia Davis. The Work of Fire. Trans. Charlotte Mandell. Stanford, CA: Stanford UP, 1995. 300-44. 
Blanchot, Maurice. "The Language of Fiction.” The Work of Fire. Trans. Charlotte Mandell. Stanford, CA: Stanford UP, 1995. 74-84.

Blanchot, Maurice. “Kafka and Literature.” The Work of Fire. Trans. Charlotte Mandell. Stanford, CA: Stanford UP, 1995. 12-26.

Blanchot, Maurice. Traduire Kafka. Eds. Eric Hoppenot, Arthur Cools, and Vivian Liska. Paris: Kimé, 2019.

Bogaerts, Jo. "Sartre, Kafka and the Universality of the Literary Work." Sartre Studies International 20.1 (2014): 69-85.

Bruns, Gerald. "Il y a, il meurt: The Theory of Writing." Maurice Blanchot: The Refusal of Philosophy. London and Baltimore, MD: Johns Hopkins UP, 1997. 56-77.

Călin, Anca. "Résister c'est créer. La résistance comme possibilité de la littérature: Sartre vs Bataille et Blanchot." Cahiers ERTA 10 (2016): 43-59.

Colin, Françoise. Maurice Blanchot et la question de l'écriture (Maurice Blanchot and the Question of Writing). Paris: Gallimard, 1971.

Critchley, Simon. Very Little... Almost Nothing: Death, Philosophy, Literature. London: Routledge, 2004 [1997].

Danta, Chris. Literature Suspends Death: Sacrifice and Storytelling in Kierkegaard, Kafka and Blanchot. London: Continuum, 2011.

Davies, Paul. “Kafka’s Lesson, Blanchot's Itenary.” Parallax 12.2 (2006): 23-39.

Denis, Benoit. "Les fins de la littérature: apories et contradictions de l'histoire littéraire sartrienne.” Fabula, 12. Oct. 2006, fabula.org/atelier.php?Les_fins_de_la_litt\%26eacute\%3Bra ture. Accessed 25 July 2020.

Derins, Françoise. “A Lecture by Jean-Paul Sartre.” October 87.4 (1999): 24-6.

Derrida, Jacques. “Introduction: Désistance.” Philippe Lacoue-Labarthe, Typography: Mimesis, Philosophy, Politics. 1-42.

Douglas, Kenneth. “Blanchot and Sartre.” Yale French Studies 3 (1949): 85-95.

Ellison, David R. "Narrative and Music in Kafka and Blanchot: The 'Singing' of Josephine." Yale French Studies 93 (1998): 196-218.

Glazova, Anna. "Kafka's Cat-Lamb: Hybridization of Genesis and Taxonomy." Kafka and the Universal. Eds. Arthur Cools and Vivian Liska. Berlin: De Gruyter, 2016. 196-212.

Guerlac, Susanne. "Sartre and the Powers of Literature: The Myth of Prose and the Practice of Reading." MLN 108.5 (1993): 805-24.

Guyer, Sara E. "The Pardon of the Disaster." SubStance 109.35 (2006): 85-105.

Hill, Leslie. Blanchot: Extreme Contemporary. London: Routledge, 1997.

Hill, Leslie. “A Kind of Struggle: Blanchot, Kafka, 'The Neuter.”' Oxford Literary Review 22 (2000): 74-93.

Hollier, Denis. Politique de la prose: Jean-Paul Sartre et l'an quarante. Paris: Gallimard, 1982.

Lacoue-Labarthe, Philippe. Typography: Mimesis, Philosophy, Politics. Stanford, CA: Stanford UP, 1998.

MacLaghlan, Ian. "Blanchot and the Romantic Imagination." Blanchot Romantique: A Collection of Essays. Eds. John McKeane and Hannes Opelz. Bern: Peter Lang, 2011. 155-72.

Mesnard, Philippe. Maurice Blanchot: Le sujet de l'engagement. Paris: L'Harmattan, 1996.

Opelz, Hannes. "Between Writing and World (Blanchot, Sartre)." New Perspectives on Sartre. Eds. Adrian Mirvish and Adrian van den Hoven. Newcastle: Cambridge Scholars Publishing, 2007. 330-66.

Opelz, Hannes. "Blanchot et Sartre: Entre écriture et le monde.” Les Temps Modernes 643-644.2 (2007): 198-246. 
Prévost, Claude. “A la recherche de Kafka (esquisse d'un bilan très provisoire)." Europe 49 (1971): 13-49.

Rajan, Tilottama. Deconstruction and the Remainders of Phenomenology: Sartre, Derrida, Foucault, Baudrillard. Stanford, CA: Stanford UP, 2002.

Robert, Marthe. Introduction à la lecture de Kafka. Paris: Editions du Sagittaire, 1946.

Robert, Marthe. "Kafka en France." Le siècle de Kafka. Eds. Yasha David and Jean-Pierre Morel. Paris: Centre Pompidou, 1984. 14-20.

Sartre, Jean-Paul. “Aminadab or the Fantastic Considered as a Language." 1947. Literary and Philosophical Essays. New York, NY: Collier, 1962. 60-77.

Sartre, Jean-Paul. "What is Literature?" Trans. Bernard Frechtman. “What is Literature?" and Other Essays. Cambridge: Harvard UP, 1988. 21-239.

Sartre, Jean-Paul. Being and Nothingness: A Phenomenological Essay on Ontology. Trans. Hazel E. Barnes. London: Routledge, 2003.

Sartre, Jean-Paul. The Imaginary: A Phenomenological Psychology of the Imagination. 1940. Trans. Jonathan Webber. London: Routledge, 2004.

Sokel, Walter. "Kafka und Sartres Existenzphilosophie.” Arcadia 5.3 (1970): 262-77.

Stoekl, Allan. “Blanchot: Death, Language, Community and Politics.” Parallax 12.2 (2006): 40-52.

Swenson, James. "Revolutionary Sentences.” Yale French Studies 93 (1998): 11-29.

Toumayan, Alain. “Blanchot, Reader of Baudelaire: ‘Baudelaire’s Failure.” After Blanchot: Literature, Criticsim, Philosophy. Eds. Leslie Hill, Brian Nelson, and Dimitris Vardoulakis. Newark, NJ: U of Delaware P, 2005. 137-48. 